\title{
Transient Receptor Potential Channels in Mechanosensing and Cell VOLUME REgULATION
}

\author{
Stine Falsig Pedersen ${ }^{\star}$ and Bernd Nilius ${ }^{\dagger}$
}

\section{Contents}

1. Introduction

2. General Mechanisms of Mechano- or Osmosensing by

Membrane Proteins

3. TRP Channels in Mechano- and Osmosensing

4. TRP Channels in Cell Volume Regulation

5. Experimental Procedures

5.1. Electrophysiological recordings used to assess mechanosensitivity of TRP channels

5.2. Electrophysiological recordings to assess osmosensitivity of TRP channels

5.3. Assessing the contribution of TRP channels to cell volume regulation: simultaneous measurements of $\left[\mathrm{Ca}^{2+}\right]_{i}$ and cell volume changes

5.4. Combined patch clamp and cell volume measurements 200

Acknowledgments 201

References

201

\begin{abstract}
Transient receptor potential (TRP) channels are unique cellular sensors responding to a wide variety of extra- and intracellular signals, including mechanical and osmotic stress. In recent years, TRP channels from multiple subfamilies have been added to the list of mechano- and/or osmosensitive channels, and it is becoming increasingly apparent that $\mathrm{Ca} 2+$ influx via TRP channels plays a crucial role in the response to mechanical and osmotic perturbations in a wide range of cell types. Although the events translating mechanical and osmotic stimuli into regulation of TRP channels are still incompletely understood, the specific mechanisms employed vary between different TRP isoforms, and probably include changes in
\end{abstract}

\footnotetext{
* Department of Molecular Biology, University of Copenhagen, DK-2100 Copenhagen Ø, Denmark

Laboratorium voor Fysiologie, KU Leuven, Campus Gasthuisberg, B-3000 Leuven, Belgium 
the tension and/or curvature of the lipid bilayer, changes in the cortical cytoskeleton, and signaling events such as lipid metabolism and protein phosphorylation/ dephosphorylation. This chapter describes candidate mechanosensitive channels from mammalian TRP subfamilies, discusses inherent and technical issues potentially confounding evaluation of mechano- and/or osmosensitivity, and presents methods relevant to the study of TRP channel regulation by mechanical and osmotic stimuli and involvement in cell volume regulation.

\section{INTRODUCTION}

Transient receptor potential (TRP) channels are unique cellular sensors, the important roles of which include the detection of mechanical forces and of changes in cell volume or intra- or extracellular osmolarity. Based on sequence homology, mammalian TRP channels are divided into six subfamilies: TRPC (canonical), TRPV (vanilloid), TRPM (melastatin), TRPP (polycystin), TRPML (mucolipin), and TRPA (ankyrin). Most TRPs are polymodal channels activated by multiple physical and chemical stimuli through distinct molecular mechanisms (for reviews, see Liedtke, 2005; Liedtke and Kim, 2005; Nilius and Voets, 2005; Nilius et al., 2007; Pedersen et al., 2005; Ramsey et al., 2006; Voets et al., 2005). The first evidence for an involvement of TRP channels in mechanosensation came from mutations in the Caenorhabditis elegans osm-9 gene, which encodes a TRPV-like channel. Worms with mutations in this channel were shown to exhibit defects in the avoidance reaction to high osmolality and nose touch (Colbert et al., 1997). In recent years, pivotal roles of mammalian TRP channels in mechano- and osmosensing have been demonstrated. This chapter briefly describes these channels and the evidence linking them to mechano- and osmosensing and discusses methods relevant to the study of TRP channel regulation by mechanical and osmotic stimuli and the potential involvement of TRP channels in the regulation of cell volume.

\section{General Mechanisms of Mechano- or Osmosensing by Membrane Proteins}

Membrane transport proteins appear to sense mechanical forces and/or changes in osmolarity by a number of fundamental mechanisms. These are outlined in 1and discussed later, focusing on the mechanisms relevant to ion channels in general and TRP channels in particular (for reviews on general mechanisms of mechanotransduction, see Hamill and Martinac, 2001; Kung, 2005; Nicolson, 2005; Perozo, 2006). Any channel embedded in a lipid bilayer is exposed to negative and positive pressures created by the bilayer. Under equilibrium conditions, the conformational energy of the channel 
matches this energy profile. Any change of this equilibrium can result in modulation of channel activity (Fig. 10.1A). A number of mechanisms have been shown to be involved in mechano-/osmosensing by plasma membrane ion channels. First, a change of the forces acting within the lipid membrane causes conformational changes in the channel protein. In this manner, forces acting at the crucial lipid-protein interface may gate a channel upon membrane stretch or bending (Fig. 10.1B). Second, channel displacement through a tether, for example, a reorganization of the cortical cytoskeleton, can cause a mismatch between the conformation energy of the channel and the intrinsic lipid tension, leading to changes in channel gating (Fig. 10.1C). Third, changes in the membrane content of specific lipids (e.g., phosphatidylcholines, lysophosphatidylcholines, or arachidonic acid and its metabolites) can alter the membrane structure around a channel protein in a concave or a convex manner, depending on the shape of the relevant lipid components, thereby inducing energetic mismatch and changes in channel gating (Fig. 10.1D). The two pore potassium channels, TREK-1 and TRAAK, provide interesting examples of gating by changes in membrane lipid composition. A phospholipid sensor controls mechanoactivation of TREK-1 and phosphatidylinositol (4,5)-bisphosphate $\left[\operatorname{Ptd} \operatorname{Ins}(4,5) \mathrm{P}_{2}\right]$ sensitizes its activation, and TRAAK is activated by convex bending of the membrane in a manner that can be mimicked by the introduction of membrane components causing convex membrane curvature (Chemin et al., 2005; Maingret et al., 1999; Patel and Honore, 2001; Patel et al., 1998). Fourth, mechanical or osmotic stress may trigger intracellular signaling cascades involving, for example, lipid metabolism, which may affect channel gating and/or plasma membrane insertion/retrieval (Fig. 10.1E). Fifth, mechanical or osmotic stress also elicits numerous changes in protein phosphorylation/ dephosphorylation events, several of which have been shown to play a major role in the regulation of mechano- or osmosensing by membrane transport proteins, including TRPs (for specific examples, see later) (Fig. 10.1F). A discussion of the mechanisms by which such signaling events are initiated by mechanical or osmotic stress is beyond the scope of this chapter, but important mechanisms likely involve integrin clustering, cytoskeletal reorganization, and changes in intracellular ionic strength and/or concentrations of macromolecules or specific ions (for a more general description, see Hoffmann and Pedersen, 2006; Kung, 2005). Although not further discussed here, since there is yet no evidence of such a mechanism for TRP channels, it is also notable that at least some membrane transporters appear to respond directly to volume-dependent changes in intracellular ionic strength by ionic strength-dependent interactions of a specific intracellular domain, the cystathionine $\beta$-synthase domain, with the lipid bilayer (Biemans-Oldehinkel et al., 2006).

So far, it is difficult to differentiate among mechanisms 1 through 5 just outlined. First, osmotic cell swelling can be inherently associated with 


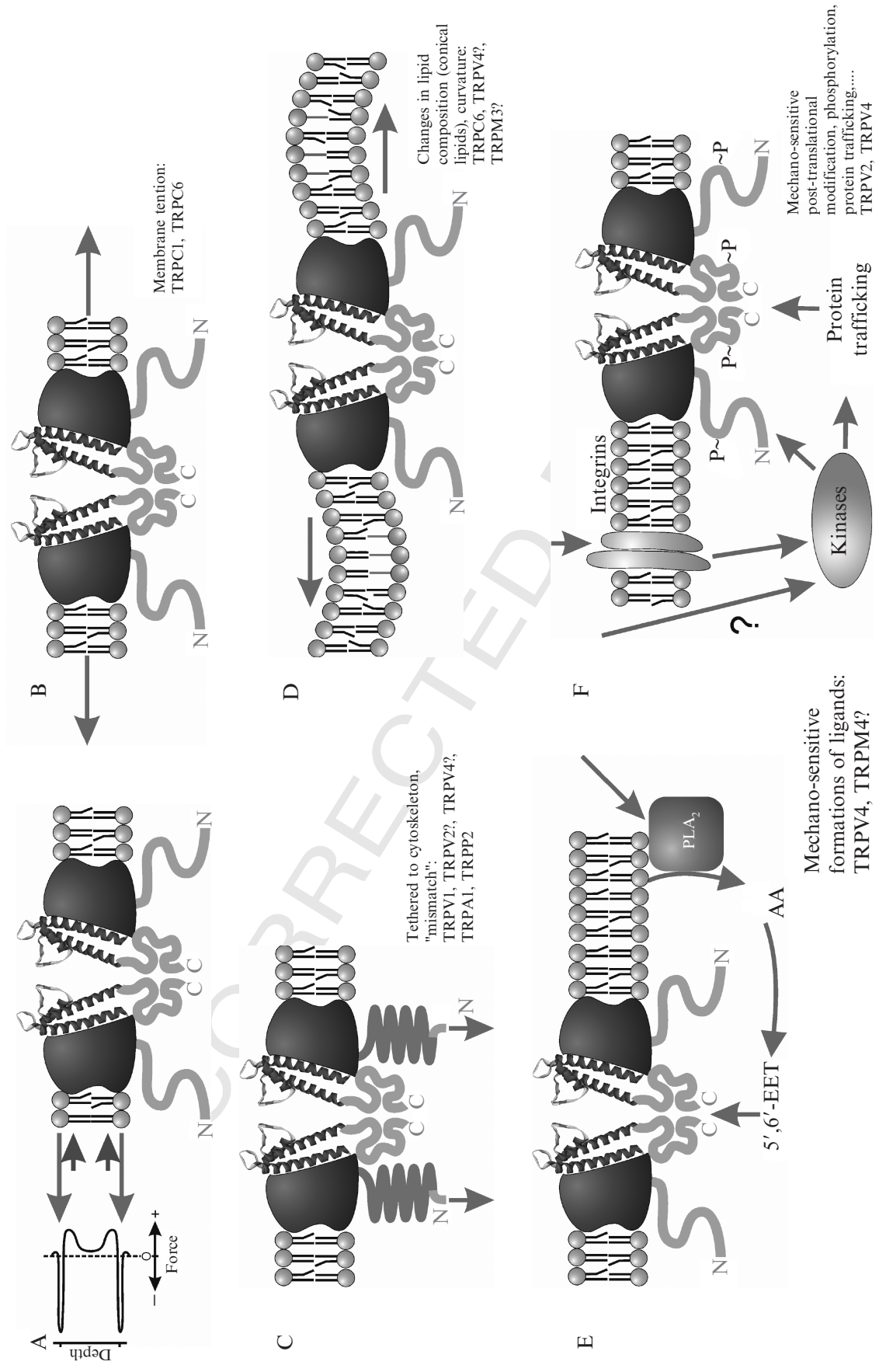


mechanical stretch and increased membrane tension (mechanism 1). However, in many cell types, cell swelling is associated with unfolding of membrane invaginations, that is, the cortical cytoskeleton is exposed to increased tension and may affect a tethered ion channel (mechanism 2). Also in accordance with this notion, cell volume perturbations elicit substantial rearrangements of the actin-based cytoskeleton (Di Ciano-Oliveira et al., 2006; Pedersen et al., 2001). In contrast, the membrane per se need not be exposed to increased tension until very substantial cell swelling has occurred (Hamill and Martinac, 2001; Maingret et al., 1999; Pedersen et al., 2001). Cell volume changes also elicit a number of signaling events involving the metabolism of membrane components, which may regulate membrane proteins both by altering bilayer curvature per se or by direct interactions of the transporter with the specific lipid messenger in question. Thus, phospholipase $\mathrm{A}_{2}\left(\mathrm{PLA}_{2}\right)$ is activated by cell swelling, leading to a breakdown of phospholipids into arachidonic acid and lysophosphatidic acid, and is conversely inhibited by cell shrinkage, leading to reduced arachidonic acid release (e.g., Basavappa et al., 1998; Pedersen et al., 2006). Moreover, hypotonic cell swelling has been shown to decrease (see Pedersen et al., 2001) and hypertonic cell shrinkage to increase (Nasuhoglu et al., 2002; Yamamoto et al., 2006) cellular PtdIns(4,5) $\mathrm{P}_{2}$ levels. Also the lipid kinase phosphatidylinositol 3-kinase (PI3K) is reported to be volume sensitive (Yamamoto et al., 2006), although the specific effects of volume perturbations on PI3K activity seem to be variable (see Pedersen et al., 2001). As discussed later, arachidonic acid metabolites, PtdIns $(4,5) \mathrm{P}_{2}$, and PI3K are involved in the regulation of several mechano- and osmosensitive TRP channels (Rohacs, 2007), and hence could play a role in messengerdependent mechano- and osmosensing (mechanism 4). Multiple protein

Figure 10.1 Some possible mechanisms of mechano- or osmosensing byTRP channels. (A) Any channel in a plasma membrane is exposed to lateral forces from the bilayer (see energy profile at the left-hand side), which create positive or negative forces (lateral pressure indicated by the arrows) acting on the channel. In equilibrium, the conformational energy of the channel matches this energy profile. Any changes in this equilibrium may cause modulation of channel activity, e.g., gating. (B) Channel gating by changes in bilayer tension, which will alter the tension profile shown in A (referred to in the text as mechanism 1). (C) Channel gating by tethering to cytoskeletal elements, which are reorganized by mechanical or osmotic stress (mechanism 2). (D) Channel gating by changes in membrane curvature (mechanism 3). (E) Channel gating by an intracellular messenger that can be produced by an enzyme acting as a mechano/osmo/ volume sensor (e.g., volume-sensitive activation of $\mathrm{PLA}_{2}$, resulting in the generation of arachidonic acid, which either itself or in the form of its downstream metabolic products gates the channel (mechanism 4). (F) Channel gating as a consequence of regulation by signaling events induced by mechanical or osmotic stress can induce signaling events, e.g., via integrins or kinases, which in turn regulate both the activity of channels resident in the plasma membrane and the membrane insertion/retrieval of channels (mechanism 5). See text for details. 
kinases and phosphatases are regulated in a volume- or mechanosensitive manner (see, e.g., Hoffmann and Pedersen, 2006), and TRP regulation by changes in protein phosphorylation/dephosphorylation may also be relevant to their mechano- and osmosensitivity (mechanism 5). One striking example is the modulation of TRPV4 by kinases of the WNK family. WNK4 downregulates TRPV4 via decreased cell surface expression. Because WNK kinases are activated by anisotonic conditions, they form a link to hypotonic TRPV4 activation (Fu et al., 2006). In yeast cells, Yvc1p, a vacuolar membrane protein with homology to TRPV (Denis and Cyert, 2002), mediates the hyperosmolarity-induced $\mathrm{Ca}^{2+}$ release, which might be regulated by intracellular phosphorylation/dephosphorylation signaling cascades (Liedtke and Kim, 2005). This cascade involves MAP kinase activation, which is triggered by Ste20, a shrinkage-activated kinase in yeast (for a review, see Strange et al., 2006). Finally, it is clear that at least some ion channels and volume-sensitive transporters respond to ionic strength rather than cell volume per se; however, the mechanisms remain to be fully elucidated and are not further discussed here (Nilius and Droogmans, 2001; Voets et al., 1999).

As evident from the discussion just given, mechano and osmo/volume/ ionic strength sensitivity are related in an inherently complex manner, yet are obviously not identical entities in terms of the biophysical characterization of membrane transporters. A number of technical aspects further complicate their experimental separation. None of the usually applied methods comply with evaluation of one of the described mechanisms in isolation. For the narrow purpose of patch clamp measurements in artificial lipid membranes-devoid of the cortical cytoskeleton-mechanosensitivity may be defined as activation by negative or positive pressure applied through the patch clamp pipette. However, a problem specifically related to analysis of mechano and osmo/volume sensitivity by the whole cell patch clamp technology is that bath hypotonicity is unavoidably coupled with a constantly increasing cell volume (see later), as well as with changes in intracellular ionic strength and concentrations of macromolecules and probably also with mechanical stimulation by fluid shear stress during cell superfusion (for discussion, see Hamill and Martinac, 2001; Nilius et al., 1998; Voets, 1999).

\section{TRP Channels in Mechano- And Osmosensing}

The ability of cells to sense mechanical stimuli is fundamental to such essential physiological functions as embryonic development, hearing, touch sensitivity, and control of kidney function, vascular tone, and muscle stretch (see, e.g., Hamill and Martinac, 2001; Kung, 2005). Multiple TRP channels from various subfamilies have been shown to be sensitive to 
various forms of mechanical stress, including fluid shear stress, and increased membrane tension resulting from membrane stretch (Liedtke and Kim, 2005; Nilius et al., 2007; O'Neil and Heller, 2005; Pedersen et al., 2005; Voets et al., 2005). This section briefly reviews the evidence for mechanoor osmo-sensitivity of individual TRP channels.

TRPC1 has been identified as a mechanosensitive cation channel (MscCa) in Xenopus laevis oocytes (Maroto et al., 2005). TRPC1 is also mechanosensitive in liposomes, and hence is probably directly activated by membrane stretch (mechanism 1). Very likely, TRPC1 is involved in stretch-induced muscle damage by elevating $\left[\mathrm{Ca}^{2+}\right]_{i}$ upon membrane stretch (Allen et al., 2005).

Another TRPC channel, the receptor-activated, nonselective cation channel TRPC6, is activated by mechanically or osmotically induced membrane stretch/deformation in a manner inhibited by the tarantula peptide toxin GsMTx-4, an inhibitor of mechanosensitive ion channels (Spassova et al., 2006). The activation mechanism is phospholipase C independent. Instead, it seems to depend directly on the lateral-lipid tension and lipid-protein mismatch, such that the stretch-induced reduction in membrane bilayer thickness alters the channel conformation to the open state (mechanism 1) (Spassova et al., 2006). Diacylglycerol, a well-known TRPC6 activator, may act similarly by changing membrane curvature, whereas GsMTx-4 may relieve membrane lipid stress and inhibit channel activation (Spassova et al., 2006). MxA, a member of the dynamin superfamily, binds to TRPC6 and connects the channel with the cytoskeleton via the second ankyrin repeat (Lussier et al., 2005). Referring to the description of mechanism 2 given earlier, it has yet to be shown that this coupling to the cytoskeleton may be involved in mechanosensing by TRPC6. Physiologically, the mechanosensitivity of TRPC6 appears to be important in the control of vascular tone in response to increased intravascular pressure (the Baylis effect) (Beech et al., 2004; Inoue et al., 2006; Welsh et al., 2002).

Finally, several TRPCs have been described as stretch-activated channels (SAC) in skeletal muscle (7-8 pS in $100 \mathrm{mM} \mathrm{Ca}^{2+}$ ), which are involved in the pathophysiology of Duchenne muscular dystrophy. These SACs are inhibited by $\mathrm{Gd}^{3+}$, SKF-96365, and GsMTx4 and are upregulated by IGF-1 (Ducret et al., 2006; Gailly, 2002; Vandebrouck et al., 2002). However, it remains to be analyzed thoroughly whether these channels, as suggested, correspond to TRPC1, TRPC3, and TRPC6 (Gailly, 2002).

A number of TRPV channels are mechano- or volume/osmosensitive. A splice variant of TRPV1, TRPV1b, in which a stretch of 60 amino acids is deleted in the intracellular N-terminal region (Lu et al., 2005), forms stretchinhibited cation channels, for example, these channels are activated by hypertonic cell shrinkage (Ciura and Bourque, 2006; Naeini et al., 2005). TRPV1b has been shown to mediate the osmosensitivity of arginine/vasopressin-releasing neurons in the supraoptic nucleus (Naeini et al., 2005). 
TRPV1 is also required for the response of osmosensory neurons in the organum vasculosum lamina terminalis, the primary osmosensor in the brain. In these neurons, hypertonic exposure activates an inward current, which is absent in trpv1-/- mice (Ciura and Bourque, 2006).

TRPV2 has been described as a stretch-activated channel functioning as a mechanosensor in vascular smooth muscle cells and also appears to be activated by osmotic cell swelling (Beech et al., 2004; Muraki et al., 2003). Stretch activation of TRPV2 has been assigned a role in skeletal and cardiac muscle degeneration caused by dystrophin-glycoprotein complex disruption (Iwata et al., 2003). The mechanism of activation of TRPV2 in response to cellular stretch/swelling is still a matter of debate. However, it is known that PI3-kinase promotes TRPV2 membrane insertion (Penna et al., 2006); it has also been discussed whether altered cellular $\operatorname{PtdIns}(4,5) \mathrm{P}_{2}$ levels may underlie TRPV2 mechanosensitivity (Yamamoto et al., 2006). Interestingly, TRPV2 interacts with a protein kinase A (PKA)-dependent signaling module, containing PKA and an A-kinase adapter protein (acylCoA-binding domain protein ACBD3), and phosphorylation by PKA may modulate mechanoactivation of TRPV2 (Stokes et al., 2004).

TRPV4 was the first TRP channel to be described as a volume-activated, $\mathrm{Ca}^{2+}$-permeable cation channel (Liedtke et al., 2000; Nilius et al., 2001; Strotmann et al., 2000). TRPV4 is activated by osmotic cell swelling in a manner that is not due to direct stretch activation (Liedtke et al., 2000; Strotmann et al., 2000), is independent of intracellular ionic strength and not reproduced by the presence of GTP $\gamma \mathrm{S}$ in the pipette solution (Nilius et al., 2001), and is not dependent on N-terminal ankyrin repeats (Liedtke et al., 2000). It has been shown that TRPV4 activation by cell swelling is mediated by the arachidonic acid metabolite $5^{\prime}, 6^{\prime}$-epoxyeicosatrienoic acid $\left(5^{\prime}, 6^{\prime}\right.$-EET) (Vriens et al., 2004, 2005; Watanabe et al., 2003), consistent with the previously demonstrated swelling-induced activation of PLA $\mathrm{P}_{2}$ (Kinnunen, 2000; Pedersen et al., 2006). Phosphorylation of TRPV4 at $\mathrm{Tyr}^{253}$ in the N-terminal region has also been proposed to play a role in channel activation by hypotonicity, although this finding has been disputed (Cohen, 2005; Xu et al., 2003). Importantly, activation of TRPV4 by cell swelling appears to be modulated by protein-protein interactions. (i) Thus swelling-induced activation of TRPV4 is absent in cystic fibrosis airway epithelial cells, suggesting a functional role of the cystic fibrosis transmembrane regulator (CFTR) in mechanosensing by TRPV4 (Arniges et al., 2004). (ii) TRPV4 activation by hypotonicity in salivary gland epithelial cells appears to depend on the interaction with its binding partner aquaporin 5 (AQP5) rather than on cell swelling directly (Liu et al., 2006). (iii) Pacsin 3, a protein thought to block dynamin-mediated endocytosis, interacts functionally with TRPV4 (Cuajungco et al., 2006), and coexpression with Pacsin 3 increases TRPV4 insertion in the plasma membrane, yet attenuates its activation by cell swelling (D'Hondt and Nilius, unpublished result). This indicates that insertion/retrieval mechanisms may 
play a role in the regulation of TRPV4 by cell swelling. Interestingly, a similar mechanism may operate in the shear stress-dependent activation of TRPM7 (see later) (Oancea et al., 2006). (iv) Finally, TRPV4 and the polycystic kidney disease protein 2 (TRPP2) colocalize in the kidney and interact in the primary cilium (Giamarchi et al., 2006), apparently forming a novel mechanosensitive complex.

TRPM3 exists as at least 12 splice variants, for which a unified nomenclature is lacking. A long splice variant (1555 amino acids) of TRPM3 forms a constitutively active channel that is further stimulated by muscarinic acetylcholine receptor activation (Grimm et al., 2003; Lee et al., 2003; Oberwinkler et al., 2005), while a shorter (1325 amino acids) human TRPM3 channel is stimulated by hypotonic cell swelling (Grimm et al., 2003) by mechanisms that remain to be elucidated.

TRPM4 has been described as a mechano-/stretch-sensitive channel involved in the control of pressure-induced smooth muscle cell depolarization and myogenic vasoconstriction in cerebral arteries and isolated vascular smooth muscle cells (Dietrich et al., 2006; Earley et al., 2004; Inoue et al., 2004, 2006; Kraft and Harteneck, 2005). However, the mechanism of activation of TRPM4 under these conditions remains to be elucidated in detail.

TRPM7 has been considered as a candidate for mechanosensation in a variety of cell types. TRPM7 has been proposed to be directly activated by cell stretch and potentiated by hypotonic cell swelling (Numata et al., 2006). Moreover, shear stress induces a translocation of TRPM7 to the plasma membrane and a rapid increase in TRPM7 currents (Oancea et al., 2006).

TRPA1 has long been considered a paradigm for a mechanosensitive channel. TRPA1 exhibits $14 \mathrm{~N}$-terminal ankyrin repeats (Lee et al., 2006; Nagata et al., 2005; Story et al., 2003), which have been speculated to act as a gating spring in mechanosensing by this channel (Howard and Bechstedt, 2004; Lee et al., 2006; Nagata et al., 2005; Sotomayor et al., 2005). TRPA1 was proposed to be the mechanically gated transduction channel necessary for the auditory response in mammals (Corey et al., 2004; Gillespie et al., 2005); however, studies in trpa1 $1^{(-/)}$mice revealed no obvious deficits in auditory function (Bautista et al., 2006; Kwan et al., 2006). Although not the auditory transduction channel, TRPA1 may well be a mechanosensory TRP channel involved in other physiological functions (Corey, 2006).

In the context of mechano- and osmosensing, it is noteworthy that in addition to ankyrin repeats, several TRP subfamilies exhibit other conserved domains potentially linking them to the actin-based cytoskeleton. Thus, direct interactions with PDZ scaffold proteins such as ezrin-binding phosphoprotein 50 (EBP50)/ $\mathrm{Na}^{+} / \mathrm{H}^{+}$exchanger regulatory factor (see Pedersen et al., 2005) link several TRP subfamilies to the ezrin/radixin/moesin proteins (Lockwich et al., 2001), which act as integrators between the F-actin cytoskeleton and 
integral membrane proteins (e.g., Bretscher et al., 2002) and which have been shown to be volume sensitive (Darborg et al., 2005; Wu et al., 2004).

Finally, the polycystic kidney disease protein 2 (PKD2 or TRPP2) is involved in mechanosensation in the primary cilia of kidney cells. In yeast, a TRPP2-like channel is involved in mechanosensing (sensing of cell shape) (Palmer et al., 2001). TRPP2 forms a complex with polycystin 1-like (PKD1), which is important for TRPP2 regulation by many stimuli; however, data from PKD1 knockout mice also point to a possible mechanosensory role for TRPP2 in the absence of PKD1 (for an excellent review, see Giamarchi et al., 2006). Trafficking of TRPP2 from the endoplasmic reticulum and the Golgi complex to the plasma membrane, where at least some mechanical forces are detected, is directed by the phosphoproteins phosphofurin acidic cluster- 1 and -2 and involves binding of these proteins to TRPP2 promoted by its phosphorylation at $\mathrm{Ser}^{812}$ by casein-kinase 2 (Köttgen and Walz, 2005; Kottgen et al., 2005). $\mathrm{Ca}^{2+}$ influx via TRPP2 translates mechanical deflections of primary cilia into a signaling cascade associated with growth control and differentiation in renal epithelial cells (Nauli and Zhou, 2004; Nauli et al., 2003). A role for TRPP2 in osmosensing has also been proposed (see, e.g., Montalbetti et al., 2005).

\section{TRP Channels in Cell Volume Regulation}

Cell volume perturbations occur under physiological and pathophysiological conditions in a wide range of cell types, and the ability to regulate cell volume is fundamental to cell function and survival. Following osmotic cell shrinkage or swelling, most cell types are able to regulate their volume in processes termed regulatory volume increase or regulatory volume decrease (RVD), respectively (Hoffmann and Pedersen, 2006; Lang et al., 1998). Obviously, to establish that a given channel actually contributes to cell volume regulation, it is not sufficient to show that it is activated by cell volume perturbations, as the effect of its activity on cell volume regulationmust be assessed. Although, as outlined earlier, a number of TRP channels have been shown to be activated by cell swelling (or swelling-induced stretch), direct evidence that TRP channels contribute to RVD is still sparse. In many cell types, increases in $\left[\mathrm{Ca}^{2+}\right]_{i}$ contribute to the RVD response after cell swelling, most commonly by the activation of $\mathrm{Ca}^{2+}$-sensitive $\mathrm{K}^{+}$channels (see Hoffmann and Pedersen, 2006). This swelling-activated increase in $\left[\mathrm{Ca}^{2+}\right]_{\text {i }}$ reflects opening of stretch-activated channels, at least some of which have now been shown or proposed to be TRP channels (e.g., Arniges et al., 2004; Maroto et al., 2005; Numata et al., 2006), and hence, the role of TRP channels in volume regulation is generally assumed to be to elicit an increase in $\left[\mathrm{Ca}^{2+}\right]_{\mathrm{i}}$. 
Among the mammalian TRP channels, a role in volume regulation has been documented most thoroughly for TRPV4. As noted earlier, TRPV4 is activated, at least in part, as a consequence of the cell swelling-induced release of 5',6'-EET (Vriens et al., 2004, 2005; Watanabe et al., 2003). Direct evidence for a role in volume regulation is available for TRPV4, as trpv4-/- mice have a reduced capacity for RVD (Liedtke and Kim, 2005), and exogenous expression of TRPV4 confers osmoregulatory capacity to CHO cells (Becker et al., 2005). Moreover, RVD was reduced markedly in cells with reduced expression of CFTR or AQP5, both of which interact with TRPV4 (Arniges et al., 2004; Liu et al., 2006). In both cases, this defect in RVD was shown to be because of a reduction of the TRPV4-mediated $\mathrm{Ca}^{2+}$ entry activated by hypotonic stimulation (Arniges et al., 2004; Liu et al., 2006).

Other TRP channels activated by cell swelling are, as noted previously, TRPV2, TRPM3, probably TRPM7, and TRPP2 (Chen and Barritt, 2003; Grimm et al., 2003; Kraft and Harteneck, 2005; Montalbetti et al., 2005; Muraki et al., 2003; Numata et al., 2006). However, although some mechanisms have been proposed, events leading to the swelling-induced activation of these channels are considerably less well understood than for TRPV4. Nonetheless, for a few of these channels, evidence has been presented for a role in the RVD process based on assessments of cell volume regulation after cell swelling. Hence, knockdown of TRPM7 (Numata et al., 2006), as well as of TRPC1 (Chen and Barritt, 2003), was found to reduce the rate of RVD (although for TRPC1 knockdown, the effect on RVD was marginal).

\section{Experimental Procedures}

This section describes the foundations and practical procedures for selected methods useful in the evaluation of mechano- and osmosensitivity, as well as of transporter effects on $\left[\mathrm{Ca}^{2+}\right]_{\mathrm{i}}$ cell volume. Standard patch clamp procedures have been described extensively elsewhere (see, e.g., Hille, 2001; Sakmann and Neher, 1995) and are not detailed here.

\subsection{Electrophysiological recordings used to assess mechanosensitivity of TRP channels}

\subsubsection{Current measurements on TRP channels expressed in mammalian cells}

Stretch sensitivity of TRP channels can be measured directly in cells endogenously expressing the channel in question or in an adequate overexpression system. A low DNA concentration should be used for transfection $(<2 \mu \mathrm{g}$ of DNA per well, see also http://www.mirusbio.com/) to 
reduce the risk of overexpression artifacts. The impact of a particular TRP channel may be studied by using specific modulators, such as $4 \alpha$ PDD for TRPV4 (Liu et al., 2006), specific antisense methods (e.g., Earley et al., 2004), gene silencing methods (see, e.g., Arniges et al., 2004; Numata et al., 2006), and constitutive or conditional knockout models (for a review, see Freichel et al., 2005). Gene silencing has been used as a powerful tool to knock down various TRP channels; however, this approach has to be used cautiously, as off-target gene silencing can present a notable challenge in the interpretation of data from siRNA experiments (Birmingham et al., 2006; Fedorov et al., 2006).

Single-channel recordings to assess channel mechanosensitivity can be performed in the cell-attached and excised inside-out configurations. In these configurations, the amplitude of the single-channel current is measured from the peak-to-peak distance on the amplitude histogram. The open probability $\left(P_{\mathrm{o}}\right)$ of the single-channel current can be calculated by dividing the total time spent in the open state by the total time of continuous recording (30-200 s) in patches containing one active channel. To test effects of mechanical stretch, patched membranes are subjected to a pulse of negative pressure applied to the back of the patch pipette by mouth or syringe. The pressure level can be monitored with a manometer or a piezoelectric pressure transducer.

\subsubsection{Current measurements on TRP channels reconstituted in liposomes}

To study mechanoactivation by membrane stretch directly, avoiding contributions from the cortical cytoskeleton, a liposome preparation may be used. Membrane proteins from an overexpression system (we routinely use HEK or CHO cells) can be reconstituted in liposomes for patch clamp recording (for details, see Hamill et al., 1981; Maroto et al., 2005; Sukharev et al., 1993). To prepare phosphatidylcholine liposomes, phosphatidylcholine is dissolved in chloroform and small aliquots of the lipid are dried under nitrogen, resuspended in $5 \mathrm{~m} M$ EDTA, $5 \mathrm{~m} M$ EGTA, $1 \mathrm{~m} M$ dithiothreitol, $50 \mathrm{mM}$ Tris-HCl, $\mathrm{pH} 7.4$, containing $2 \%$ octyl-f3-D-glucopyranoside $(\mathrm{OG})$, and bath sonicated for $5 \mathrm{~min}$. A $200-\mu \mathrm{l}$ volume (equivalent to $2 \mathrm{mg}$ lipid) is added to the membrane protein to achieve protein:lipid ratios ranging from 1:50 to 1:5000. The mixture is incubated on a platform rocker for $1 \mathrm{~h}$ at room temperature. BioBeads are then added to remove the OG, and the suspension is rocked for a further $3 \mathrm{~h}$ at room temperature. The liposomes are collected by ultracentrifugation at $90,000 \mathrm{~g}$ for $30 \mathrm{~min}$ and resuspended. Aliquots of the liposomes are spotted onto glass slides and allowed to dehydrate under vacuum at $4^{\circ}$ for $6 \mathrm{~h}$, followed by overnight rehydration (for details, see Sukharev et al., 1993).

For liposome recording, standard patch clamp techniques can be used. The liposomes are placed in a patch clamp chamber containing high $\mathrm{MgCl}_{2}$ 
solution. Seal resistance in the high $\mathrm{MgCl}_{2}$ solution should exceed $20 \mathrm{G} \Omega$. Inside-out patches can be formed by passing the pipette tip briefly through the solution-air interface. As described earlier for cellular systems, channel activation by stretch can be studied by applying negative pressure pulses (for TRPC1, -10 to $-200 \mathrm{~mm} \mathrm{Hg}$ is appropriate) (Maroto et al., 2005; Perozo, 2006).

\subsection{Electrophysiological recordings to assess osmosensitivity of TRP channels}

\subsubsection{Whole cell patch clamp and cell swelling: general considerations}

Hypotonic cell swelling in the whole cell patch clamp mode poses the inherent problem that the cell interior will constantly equilibrate with the pipette solution. As a consequence of this, the initial rapid increase in cell volume is followed by a nearly linear continuous increase until the cell ruptures (or extracellular osmolarity is restored), that is, a condition fundamentally different from that resulting from the same transmembrane osmolarity difference in an unpatched cell. In contrast to the cell volume, the current may reach a stationary level; hence, under these conditions, a close correlation between current and cell volume per se does not exist. This behavior can be explained as follows: changes in cell volume over time $(\mathrm{d} V / \mathrm{d} t)$ are a consequence of the net flux of water across the plasma membrane, which is linearly dependent on the transmembrane osmotic gradient, thus

$$
\frac{d V}{d t}=P_{W} \cdot\left(c_{i}-c_{o}\right)
$$

where $c_{\mathrm{i}}$ is the total concentration of solutes of the intracellular medium, $c_{\mathrm{O}}$ is the extracellular medium, and $P_{\mathrm{w}}$ is a constant, here referred to as "water permeation." $P_{\mathrm{W}}$ is the product of the osmotic water permeability of the membrane $\left(P_{\mathrm{f}}\right)$, the cell surface $(S)$, and the partial molar volume of water $\left(V_{\mathrm{W}}\right)$.

It is assumed that the osmotic gradient driving the water flux is approximated by the difference in total concentration of solutes and that the diffusion rate from pipette to cell is the same for all solute species in the pipette. Because of the combination of the solute exchange with the pipette and the variation in cell volume, $c_{\mathrm{i}}$ changes according to

$$
\frac{d c_{i}}{d t}=\frac{1}{V}\left(k_{d} \cdot\left(c_{p}-c_{i}\right)-c_{i} \cdot \frac{d V}{d t}\right)
$$


A

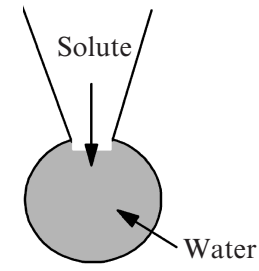

$\mathrm{d} V / \mathrm{d} t=P_{\mathrm{W}}^{*}\left(c_{\mathrm{i}}-c_{\mathrm{o}}\right)$

$\mathrm{d} c_{\mathrm{i}} / \mathrm{d} t=1 / V^{*}\left(k_{\mathrm{d}}\left(c_{\mathrm{p}}-c_{\mathrm{i}}\right)-c_{\mathrm{i}}^{*} \mathrm{~d} V / \mathrm{d} t\right)$
B

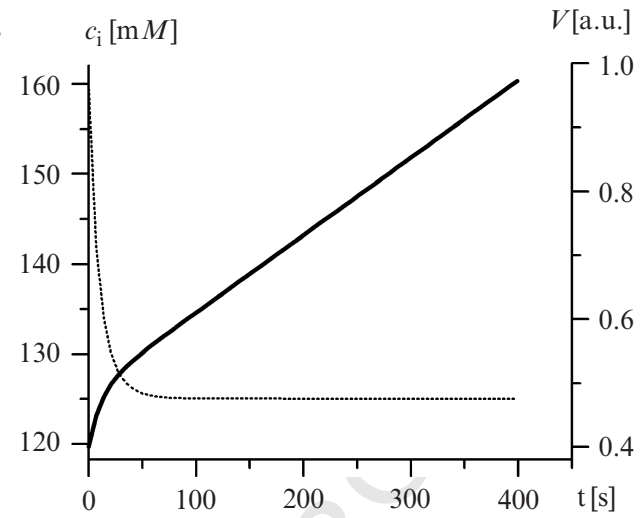

Figure 10.2 Cell volume and intracellular osmolyte concentration during exposure to hypotonic bath solutions in whole cell patch clamp experiments. If a cell is exposed to a hypotonic solution, water enters the cell and induces a change in cell volume, $\mathrm{d} V / \mathrm{d} t(\mathrm{~A})$. This increase is reflected by the initial change in volume (B, solid line). During the experiment, solutes will enter the cell from the patch pipette, which in turn induces additional water entry. Therefore, the cell volume will increase continuously (B). The intracellular osmolyte concentration, $c_{i}$ (dotted line), decreases rapidly and reaches a stationary constant value while the volume is constantly increasing. See text for details.

where the constant $k_{\mathrm{d}}$ describes the rate of diffusion of solutes from pipette to cell and $c_{\mathrm{i}}$ and $c_{\mathrm{p}}$ reflect the global concentrations of solutes in the cell and in the pipette, respectively. Thus, hypotonic cell swelling in the whole cell patch clamp mode can be described by a system of two differential equations with the variables $c_{\mathrm{i}}$ and $V$. Figure 10.2 shows a numerical solution of this system of differential equations. The initial slope of the volume change mainly reflects the influx of water across the plasma membrane, which is faster than the solute exchange via the patch pipette. The subsequent nearly linear increase in volume is a consequence of the exchange of solutes via the patch pipette. Importantly, this model predicts that $c_{\mathrm{i}}$ decreases significantly during an osmotic challenge and reaches a plateau value, despite the continuous increase in cell volume. For further details, see Nilius (2004) and Voets et al. (1999).

\subsubsection{Practical procedures}

Similar to stretch sensitivity, volume/osmosensitivity of TRP channels may be assessed either in cells endogenously expressing the channel in question or after channel expression in a cell type with low endogenous TRP levels such as HEK 293 cells. For measurements of the volume sensitivity of TRP channels in the whole cell patch clamp mode in mammalian cells, we 
generally employ an isotonic solution containing (in $\mathrm{mM}$ ) $105 \mathrm{NaCl}$, $6 \mathrm{CsCl}, 5 \mathrm{CaCl}_{2}, 1 \mathrm{MgCl}_{2}, 10 \mathrm{HEPES}, 90 \mathrm{D}$-mannitol, 10 glucose, buffered $\mathrm{pH} 7.4$ with $\mathrm{NaOH}(320 \pm 5 \mathrm{mOsm})$. Cell swelling can thus be induced at constant extracellular ionic strength by omitting the desired amount of mannitol from this solution. The pipette solution for such experiments is generally composed of (in $\mathrm{mM}$ ) $20 \mathrm{CsCl}, 100 \mathrm{Asp}, 1 \mathrm{MgCl}_{2}, 10 \mathrm{HEPES}$, $4 \mathrm{Na}_{2} \mathrm{ATP}, 10$ BAPTA, and an equivalent amount of $\mathrm{CaCl}_{2}$ to buffer $\left[\mathrm{Ca}^{2+}\right]_{\mathrm{i}}$ at an required level (for calculation of free intracellular divalent concentrations, we refer to the CaBuf program ftp://ftp.cc.kuleuven.ac.be/ pub/droogmans/cabuf.zip).

\subsection{Assessing the contribution of TRP channels to cell volume regulation: simultaneous measurements of $\left[\mathrm{Ca}^{2+}\right]_{i}$ and cell volume changes}

\subsubsection{General considerations}

Changes in $\left[\mathrm{Ca}^{2+}\right]_{i}$ and cell volume can conveniently be assessed simultaneously in a cell population using the fluorescent $\mathrm{Ca}^{2+}$-sensitive probe Fura2 in conjunction with large-angle light scattering. Ratiometric measurements of $\left[\mathrm{Ca}^{2+}\right]_{i}$ using Fura-2 are widely used and described extensively elsewhere (Grynkiewicz et al., 1985; Tsien, 1989). Large-angle light scattering is a noninvasive and sensitive technique for evaluating volume changes in both adherent and suspended cells, exploiting the fact that the light-scattering properties of cells are altered upon cell volume changes. While smaller particles scatter light in all directions, large particles scatter predominantly in the nearforward direction. A cell scatters light both as a large particle and as a collection of small particles reflecting its internal composition, hence both forward and large-angle light scattering are volume sensitive, although the latter appears to be the more sensitive method (Latimer, 1982; McManus et al., 1993; Meyer and Brunsting, 1975). Generally, large-angle light scattering is inversely related to cell volume, consistent with a dependence on the cellular concentration of scattering particles (Fischbarg et al., 1989; Latimer, 1982; McManus et al., 1993). The only real disadvantage to the light-scattering technique is that absolute cell volumes cannot be obtained in this manner; however, for evaluation of RVD rates, this is rarely a problem.

\subsubsection{Practical procedures}

Cells are seeded $24 \mathrm{~h}$ prior to experiments on $10 \times 50-\mathrm{mm}, \mathrm{HCl}-$ and ethanol-washed coverslips to a confluency of 70 to $90 \%$ at the time of the experiments. Cells are loaded with Fura- 2 by preincubation with $2 \mu M$ Fura-2 acetoxymethyl ester (Fura-2-AM) in standard isotonic medium for $20 \mathrm{~min}$ at $37^{\circ}$ followed by a wash and a 15 -min postloading incubation to ensure proper intracellular cleavage of the acetoxymethylester groups to obtain Fura-2. 


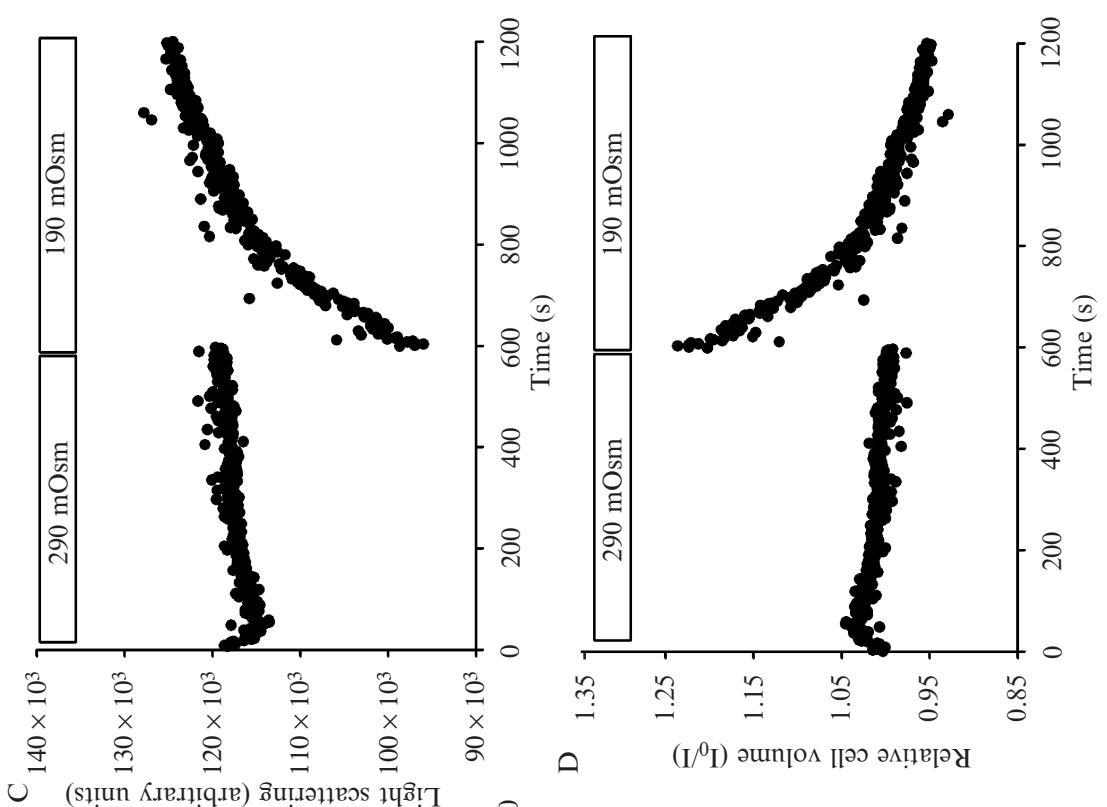

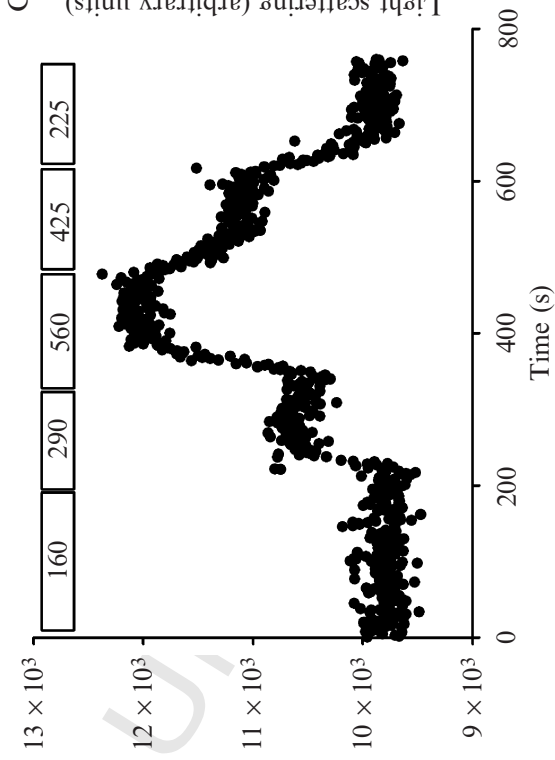

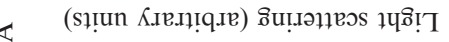

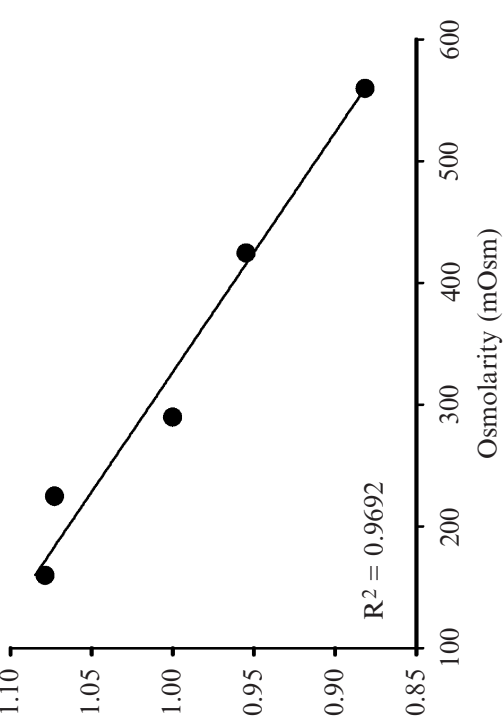

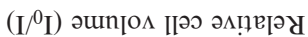


We employ a PTI RatioMaster spectrophotometer equipped with a standard photomultiplier (PMT) system, excitation and emission monochrometers for wavelength selection, a 75-W xenon lamp, and a temperature-controlled cuvette house. During experiments, the cuvette is perfused continuously with preheated $\left(37^{\circ}\right)$ standard Ringer's solutions at a speed of about $0.7 \mathrm{ml} / \mathrm{min}$, increasing to $3.5 \mathrm{ml} / \mathrm{min}$ during solution changes for rapid complete exchange in the cuvette. The coverslip with the cells is placed at a $50^{\circ}$ angle relative to the excitation light, and scattered light is collected at an angle of $90^{\circ}$ relative to the excitation light. Excitation and emission wavelengths for light scattering need to be optimized for each cell type used. Generally, the best light-scattering signal is obtained after excitation in the wavelength range of 570 to $600 \mathrm{~nm}$. The emission wavelength is set about $5 \mathrm{~nm}$ red shifted to the excitation wavelength to protect the PMT from excitation light. To the extent that the cells swell as nearperfect osmometers, and in the absence of volume regulation, the lightscattering signal will be a linear function of the osmolarity. Practically, this is achieved by very rapid solution changes, such that volume regulation is negligible in the time window studied.

Figure 10.3A and B show an experiment evaluating the linearity of the light-scattering response to osmolarity changes in Ehrlich-Lettre ascites (ELA) murine tumor cells. With these cells, the optimal light-scattering signal in our setup is obtained at $589 \mathrm{~nm}$ excitation, and emission is measured at $595 \mathrm{~nm}$. Figure 10.3A is a representative trace, and it is seen that the light-scattering signal is directly related to extracellular osmolarity, that is, inversely related to cell volume. Therefore, data are calculated as the inverse of the light-scattering signal relative to that obtained in the initial, isotonic condition $\left(\mathrm{I}_{0}\right)$, that is, $1 /\left(\mathrm{I} / \mathrm{I}_{0}\right)$, or $\mathrm{I}_{0} / \mathrm{I}$. Figure $10.3 \mathrm{~B}$ shows $\mathrm{I}_{0} / \mathrm{I}$ from the experiment in Fig. 10.3A as a function of extracellular osmolarity. Figures $10.3 \mathrm{C}$ and $10.3 \mathrm{D}$ show the light-scattering signal, and $\mathrm{I}_{0} / \mathrm{I}$, for an

Figure 10.3 The use of large-angle light scattering to monitor cell volume changes. (A) Light scattering as a function of extracellular osmolarity in Ehrlich Lettre ascites cells. Cells were seeded $24 \mathrm{~h}$ prior to experiments on $10 \times 50-\mathrm{mm}$ coverslips to a confluency of about $70 \%$ at the time of the experiments. Cells were mounted in a temperature-controlled cuvette in a PTI RatioMaster spectrophotometer and were perfused continuously with preheated $\left(37^{\circ}\right)$ Ringer's solutions, which were changed rapidly to the osmolarity indicated by increasing the perfusion rate from 0.7 to $3.5 \mathrm{ml} / \mathrm{min}$. Excitation was measured at $589 \mathrm{~nm}$ excitation, and emission is measured at $595 \mathrm{~nm}$. (B) Data from A were converted to relative cell volumes by calculating the inverse of the light-scattering signal relative to that obtained in the initial, isotonic condition $\left(\mathrm{I}_{0}\right)$, i.e., $1 /\left(\mathrm{I} / \mathrm{I}_{0}\right)$, or $\mathrm{I}_{0} / \mathrm{I}$. (C and D) Raw data and $\mathrm{I}_{0} / \mathrm{I}$ for an experiment assessing RVD in about $90 \%$ confluent ELA cells after a $35 \%$ reduction in extracellular osmolarity. The experiment was carried out as described in A. It may be noted that the magnitude of the light-scattering signal, as well as of the relative changes in light scattering, is strongly cell density dependent, hence only populations of equal confluency should be compared. 
experiment assessing RVD in ELA cells after a 35\% reduction in extracellular osmolarity. RVD may be calculated as the slope of the initial, linear part of the relative cell volume traces following maximal cell swelling (for further examples, see Pedersen et al., 2002).

The simultaneous assessments of Fura- 2 fluorescence are carried out by measuring at $510 \mathrm{~nm}$ after excitation at 340 and $380 \mathrm{~nm}$. Practically, this is achieved by running continuous cycles of excitation and measurement, such that cells are excited at $589 \mathrm{~nm}$ and emission is measured at $595 \mathrm{~nm}$, followed by excitation at 340 and $380 \mathrm{~nm}$, respectively, and emission measurement at $510 \mathrm{~nm}$. Fura-2 data are evaluated as the 340/380-nm ratio after background subtraction and may be converted to $\left[\mathrm{Ca}^{2+}\right]_{\mathrm{i}}$ values by in vitro calibration as described previously (Grynkiewicz et al., 1985). In our hands, Fura-2 loading has no effect on the light-scattering measurements.

\subsection{Combined patch clamp and cell volume measurements}

\subsubsection{General considerations}

A combination of volume measurements and patch clamp can be used on larger cells (e.g., epithelial or endothelial cells) adhering to a coated coverslip. The general problem of using whole cell patch clamp in conjunction with hypotonic cell swelling has already been discussed in detail. It should be carefully taken into account that the cell volume of the patched cells increased constantly and never reached a steady state and evaluated how much this unavoidable pitfall influences the conclusions drawn by the experimentalist.

\subsubsection{Practical procedures}

We have used a method for simultaneous monitoring of the cell height and whole cell currents. This method is useful for flat and adhering cells (e.g., endothelial or epithelial cells), which do not change the surface area attached to the coverslip during swelling. It is not usable for small, round, nonadhering cells, such as HEK cells. Currents are measured in the normal whole cell patch clamp configuration. We measure simultaneously the cell surface area (CSA) of the patched single cells, which is quantified from digital images recorded with a video camera (Model CF 6, Kappa, Gleichen, Germany) (Voets et al., 1999). Cell borders are traced manually, and the surface of the traced region is determined using IMAGETOOL 1.25 software (University of Texas Health Science Center, San Antonio, TX) (for more details concerning the measurement of cell height without patch clamping, see Van Driessche et al., 1993). CSA is calculated as the average of three independent tracing procedures. Simultaneously, cell thickness, $T_{\mathrm{c}}$, is monitored constantly as described previously (Van Driessche et al., 1993). Briefly, gelatin-coated coverslips containing nonconfluent endothelial cells are incubated for about $30 \mathrm{~min}$ with $4 \mu \mathrm{l} / \mathrm{ml}$ Red Neutravidin-labeled 
microbeads (F-8775, Molecular Probes), followed by a 15-min washing with microbead-free solution. Visualization of the microbeads is performed using a xenon lamp and the XF40/E filter set (Omega Optical, Brattleboro, VT). Fluorescent images at different vertical positions are recorded with the CF 6 video camera, digitized, and displayed on a video monitor. Vertical displacement is achieved using a low-voltage piezoelectric translator (PIFOC P-721; Physik Instrumente, Waldbronn, Germany). $T_{\mathrm{c}}$ is calculated as the vertical distance between beads on the gelatin surface and on the cell surface, and image analysis is performed online (for details, see Voets et al., 1999).

\section{ACKNOWLEDGMENTS}

We thank Dr. Greg Owsianik (Leuven) for his help with Fig. 10.1 Work in the authors' laboratories is supported by the Danish National Research Council (SFP, Grants 21-04-0507 and 272-05-0305) and Human Frontiers Science Programme (HFSP Research Grant Ref. RGP 32/2004), the Belgian Federal Government, the Flemish Government, and the Onderzoeksraad KU Leuven (GOA 2004/07, F.W.O. G. 0136.00; F.W.O. G.0172.03, Interuniversity Poles of Attraction Program, Prime Ministers Office IUAP Nr.3P4/23, Excellentiefinanciering EF/95/010) (BN).

\section{REFERENCES}

Allen, D. G., Whitehead, N. P., and Yeung, E. W. (2005). Mechanisms of stretch-induced muscle damage in normal and dystrophic muscle: Role of ionic changes. J. Physiol. 567, 723-735.

Arniges, M., Vazquez, E., Fernandez-Fernandez, J. M., and Valverde, M. A. (2004). Swelling-activated $\mathrm{Ca}^{2+}$ entry via TRPV4 channel is defective in cystic fibrosis airway epithelia. J. Biol. Chem. 279, 54062-54068.

Basavappa, S., Pedersen, S. F., Jorgensen, N. K., Ellory, J. C., and Hoffmann, E. K. (1998). Swelling-induced arachidonic acid release via the 85-kDa cPLA2 in human neuroblastoma cells. J. Neurophysiol. 79, 1441-1449.

Bautista, D. M., Jordt, S. E., Nikai, T., Tsuruda, P. R., Read, A. J., Poblete, J., Yamoah, E. N., Basbaum, A. I., and Julius, D. (2006). TRPA1 mediates the inflammatory actions of environmental irritants and proalgesic agents. Cell 124, 1269-1282.

Becker, D., Blase, C., Bereiter-Hahn, J., and Jendrach, M. (2005). TRPV4 exhibits a functional role in cell-volume regulation. J. Cell Sci. 118, 2435-2440.

Beech, D. J., Muraki, K., and Flemming, R. (2004). Non-selective cationic channels of smooth muscle and the mammalian homologues of Drosophila TRP. J. Physiol. 559, 685-706.

Biemans-Oldehinkel, E., Mahmood, N. A., and Poolman, B. (2006). A sensor for intracellular ionic strength. Proc. Natl. Acad. Sci. USA 103, 10624-10629.

Birmingham, A., Anderson, E. M., Reynolds, A., Ilsley-Tyree, D., Leake, D., Fedorov, Y., Baskerville, S., Maksimova, E., Robinson, K., Karpilow, J., Marshall, W. S., and Khvorova, A. (2006). 3' UTR seed matches, but not overall identity, are associated with RNAi off-targets. Nat. Methods 3, 199-204.

Bretscher, A., Edwards, K., and Fehon, R. G. (2002). ERM proteins and merlin: Integrators at the cell cortex. Nat. Rev. Mol. Cell. Biol. 3, 586-599. 
Chemin, J., Patel, A. J., Duprat, F., Lauritzen, I., Lazdunski, M., and Honore, E. (2005). A phospholipid sensor controls mechanogating of the $\mathrm{K}^{+}$channel TREK-1. EMBO J. 24, 44-53.

Chen, J., and Barritt, G. J. (2003). Evidence that TRPC1 (transient receptor potential canonical 1) forms a $\mathrm{Ca}^{2+}$-permeable channel linked to the regulation of cell volume in liver cells obtained using small interfering RNA targeted against TRPC1. Biochem. J. 373, 327-336.

Ciura, S., and Bourque, C. W. (2006). Transient receptor potential vanilloid 1 is required for intrinsic osmoreception in organum vasculosum lamina terminalis neurons and for normal thirst responses to systemic hyperosmolality. J. Neurosci. 26, 9069-9075.

Cohen, D. M. (2005). TRPV4 and the mammalian kidney. Pflüg. Arch. Eur. J. Physiol. 451, 168-175.

Colbert, H. A., Smith, T. L., and Bargmann, C. I. (1997). OSM-9, a novel protein with structural similarity to channels, is required for olfaction, mechanosensation, and olfactory adaptation in Caenorhabditis elegans. J. Neurosci. 17, 8259-8269.

Corey, D. P. (2006). What is the hair cell transduction channel? J. Physiol. 576, 23-28.

Corey, D. P., Garcia-Anoveros, J., Holt, J. R., Kwan, K. Y., Lin, S. Y., Vollrath, M. A., Amalfitano, A., Cheung, E. L., Derfler, B. H., Duggan, A., Geleoc, G. S., Gray, P. A., et al. (2004). TRPA1 is a candidate for the mechanosensitive transduction channel of vertebrate hair cells. Nature 432, 723-730.

Cuajungco, M. P., Grimm, C., Oshima, K., D’Hoedt, D., Nilius, B., Mensenkamp, A. R., Bindels, R. J., Plomann, M., and Heller, S. (2006). PACSINs bind to the TRPV4 cation channel: PACSIN 3 modulates the subcellular localization of TRPV4. J. Biol. Chem. 281, 18753-18762.

Darborg, B., Hoffmann, E. K., and Pedersen, S. F. (2005). Causal relationship between NHE1, NKCC1, MAPKs and ERM proteins after osmotic shrinkage in Ehrlich Lettre mouse ascites tumor cells. FASEB J. 19, A115.

Denis, V., and Cyert, M. S. (2002). Internal $\mathrm{Ca}^{2+}$ release in yeast is triggered by hypertonic shock and mediated by a TRP channel homologue. J. Cell Biol. 156, 29-34.

Di Ciano-Oliveira, C., Thirone, A. C., Szaszi, K., and Kapus, A. (2006). Osmotic stress and the cytoskeleton: the R(h)ole of Rho GTPases. Acta Physiol. (Oxf.) 187, 257-272.

Dietrich, A., Chubanov, V., Kalwa, H., Rost, B. R., and Gudermann, T. (2006). Cation channels of the transient receptor potential superfamily: Their role in physiological and pathophysiological processes of smooth muscle cells. Pharmacol. Ther. 112, 744-760.

Ducret, T., Vandebrouck, C., Cao, M. L., Lebacq, J., and Gailly, P. (2006). Functional role of store-operated and stretch-activated channels in murine adult skeletal muscle fibres. J. Physiol. 575, 913-924.

Earley, S., Waldron, B. J., and Brayden, J. E. (2004). Critical role for transient receptor potential channel TRPM4 in myogenic constriction of cerebral arteries. Circ. Res. 95, 922-929.

Fedorov, Y., Anderson, E. M., Birmingham, A., Reynolds, A., Karpilow, J., Robinson, K., Leake, D., Marshall, W. S., and Khvorova, A. (2006). Off-target effects by siRNA can induce toxic phenotype. RNA 12, 1188-1196.

Fischbarg, J., Kuang, K. Y., Hirsch, J., Lecuona, S., Rogozinski, L., Silverstein, S. C., and Loike, J. (1989). Evidence that the glucose transporter serves as a water channel in J774 macrophages. Proc. Natl. Acad. Sci. USA 86, 8397-8401.

Freichel, M., Vennekens, R., Olausson, J., Stolz, S., Philipp, S. E., Weissgerber, P., and Flockerzi, V. (2005). Functional role of TRPC proteins in native systems: Implications from knockout and knock-down studies. J. Physiol. 567, 59-66.

Fu, Y., Subramanya, A., Rozansky, D., and Cohen, D. M. (2006). WNK kinases influence TRPV4 channel function and localization. Am. J. Physiol. Renal Physiol. 290, F1305-F1314. 
Gailly, P. (2002). New aspects of calcium signaling in skeletal muscle cells: Implications in Duchenne muscular dystrophy. Biochim. Biophys. Acta 1600, 38-44.

Giamarchi, A., Padilla, F., Coste, B., Raoux, M., Crest, M., Honore, E., and Delmas, P. (2006). The versatile nature of the calcium-permeable cation channel TRPP2. EMBO Rep. 7, 787-793.

Gillespie, P. G., Dumont, R. A., and Kachar, B. (2005). Have we found the tip link, transduction channel, and gating spring of the hair cell? Curr. Opin. Neurobiol. 15, 389-396.

Grimm, C., Kraft, R., Sauerbruch, S., Schultz, G., and Harteneck, C. (2003). Molecular and functional characterization of the melastatin-related cation channel TRPM3. J. Biol. Chem. 278, 21493-21501.

Grynkiewicz, G., Poenie, M., and Tsien, R. Y. (1985). A new generation of $\mathrm{Ca}^{2+}$ indicators with greatly improved fluorescence properties. J. Biol. Chem. 260, 3440-3450.

Hamill, O. P., and Martinac, B. (2001). Molecular basis of mechanotransduction in living cells. Physiol. Rev. 81, 685-740.

Hamill, O. P., Marty, A., Neher, E., Sakmann, B., and Sigworth, F. J. (1981). Improved patch-clamp techniques for high-resolution current recording from cells and cell-free membrane patches. Pflüg. Arch. Eur. J. Physiol. 391, 85-100.

Hille, B. (2001). "Ionic Channels of Excitable Membranes." Sinauer, Sunderland, MA.

Hoffmann, E. K., and Pedersen, S. F. (2006). Sensors and signal transduction pathways in vertebrate cell volume regulation. Contrib. Nephrol. 152, 54-104.

Howard, J., and Bechstedt, S. (2004). Hypothesis: A helix of ankyrin repeats of the NOMPC-TRP ion channel is the gating spring of mechanoreceptors. Curr. Biol. 14, R224-R226.

Inoue, R., Jensen, L. J., Shi, J., Morita, H., Nishida, M., Honda, A., and Ito, Y. (2006). Transient receptor potential channels in cardiovascular function and disease. Circ. Res. 99, 119-131.

Inoue, R., Morita, H., and Ito, Y. (2004). Newly emerging Ca2+ entry channel molecules that regulate the vascular tone. Expert Opin. Ther. Targets 8, 321-334.

Iwata, Y., Katanosaka, Y., Arai, Y., Komamura, K., Miyatake, K., and Shigekawa, M. (2003). A novel mechanism of myocyte degeneration involving the $\mathrm{Ca}^{2+}$-permeable growth factor-regulated channel. J. Cell Biol. 161, 957-967.

Kinnunen, P. K. (2000). Lipid bilayers as osmotic response elements. Cell Physiol. Biochem. 10, 243-250.

Kottgen, M., Benzing, T., Simmen, T., Tauber, R., Buchholz, B., Feliciangeli, S., Huber, T. B., Schermer, B., Kramer-Zucker, A., Hopker, K., Simmen, K. C., Tschucke, C. C., et al. (2005). Trafficking of TRPP2 by PACS proteins represents a novel mechanism of ion channel regulation. EMBO J. 24, 705-716.

Köttgen, M., and Walz, G. (2005). Subcellular localization and trafficking of polycystins. Pflüg. Arch. Eur. J. Physiol. 451, 286-293.

Kraft, R., and Harteneck, C. (2005). TRPM cation channels: An overview. Pflüg. Arch. Eur. J. Physiol. 451, 204-211.

Kung, C. (2005). A possible unifying principle for mechanosensation. Nature 436, 647-654.

Kwan, K. Y., Allchorne, A. J., Vollrath, M. A., Christensen, A. P., Zhang, D. S., Woolf, C. J., and Corey, D. P. (2006). TRPA1 contributes to cold, mechanical, and chemical nociception but is not essential for hair-cell transduction. Neuron 50, 277-289.

Lang, F., Busch, G. L., Ritter, M., Volkl, H., Waldegger, S., Gulbins, E., and Haussinger, D. (1998). Functional significance of cell volume regulatory mechanisms. Physiol. Rev. 78, 247-306.

Latimer, P. (1982). Light scattering and absorption as methods of studying cell population parameters. Annu. Rev. Biophys. Bioeng. 11, 129-150. 
Lee, G., Abdi, K., Jiang, Y., Michaely, P., Bennett, V., and Marszalek, P. E. (2006). Nanospring behaviour of ankyrin repeats. Nature 440, 246-249.

Lee, N., Chen, J., Sun, L., Wu, S., Gray, K. R., Rich, A., Huang, M., Lin, J. H., Feder, J. N., Janovitz, E. B., Levesque, P. C., and Blanar, M. A. (2003). Expression and characterization of human transient receptor potential melastatin 3 (hTRPM3). J. Biol. Chem. 278, 20890-20897.

Liedtke, W. (2005). TRPV4 as osmosensor: A transgenic approach. Pflüg. Arch. 451, 176-280.

Liedtke, W., Choe, Y., Marti-Renom, M. A., Bell, A. M., Denis, C. S., Sali, A., Hudspeth, A. J., Friedman, J. M., and Heller, S. (2000). Vanilloid receptor-related osmotically activated channel (VR-OAC), a candidate vertebrate osmoreceptor. Cell 103, 525-535.

Liedtke, W., and Kim, C. (2005). Functionality of the TRPV subfamily of TRP ion channels: Add mechano-TRP and osmo-TRP to the lexicon! Cell. Mol. Life Sci. 62, 2985-3001.

Liu, X., Bandyopadhyay, B., Nakamoto, T., Singh, B., Liedtke, W., Melvin, J. E., and Ambudkar, I. (2006). A role for AQP5 in activation of TRPV4 by hypotonicity: Concerted involvement of AQP5 and TRPV4 in regulation of cell volume recovery. J. Biol. Chem. 281, 15485-15495.

Lockwich, T., Singh, B. B., Liu, X., and Ambudkar, I. S. (2001). Stabilization of cortical actin induces internalization of transient receptor potential 3 (Trp3)-associated caveolar $\mathrm{Ca}^{2+}$ signaling complex and loss of $\mathrm{Ca}^{2+}$ influx without disruption of Trp3-inositol trisphosphate receptor association. J. Biol. Chem. 276, 42401-42408.

Lu, G., Henderson, D., Liu, L., Reinhart, P. H., and Simon, S. A. (2005). TRPV1b: A functional human vanilloid receptor splice variant. Mol. Pharmacol. 67, 1119-1127.

Lussier, M. P., Cayouette, S., Lepage, P. K., Bernier, C. L., Francoeur, N., St-Hilaire, M., Pinard, M., and Boulay, G. (2005). MxA, a member of the dynamin superfamily, interacts with the ankyrin-like repeat domain of TRPC. J. Biol. Chem. 280, 19393-19400.

Maingret, F., Fosset, M., Lesage, F., Lazdunski, M., and Honore, E. (1999). TRAAK is a mammalian neuronal mechano-gated $\mathrm{K}^{+}$channel. J. Biol. Chem. 274, 1381-1387.

Maroto, R., Raso, A., Wood, T. G., Kurosky, A., Martinac, B., and Hamill, O. P. (2005). TRPC1 forms the stretch-activated cation channel in vertebrate cells. Nat. Cell Biol. 7, 179-185.

McManus, M., Fischbarg, J., Sun, A., Hebert, S., and Strange, K. (1993). Laser lightscattering system for studying cell volume regulation and membrane transport processes. Am. J. Physiol. 265, C562-C570.

Meyer, R. A., and Brunsting, A. (1975). Light scattering from nucleated biological cells. Biophys. J. 15, 191-203.

Montalbetti, N., Li, Q., Gonzalez-Perrett, S., Semprine, J., Chen, X. Z., and Cantiello, H. F. (2005). Effect of hydro-osmotic pressure on polycystin-2 channel function in the human syncytiotrophoblast. Pflüg. Arch. Eur. J. Physiol. 451, 294-303.

Muraki, K., Iwata, Y., Katanosaka, Y., Ito, T., Ohya, S., Shigekawa, M., and Imaizumi, Y. (2003). TRPV2 is a component of osmotically sensitive cation channels in murine aortic myocytes. Circ. Res. 93, 829-838.

Naeini, R. S., Witty, M. F., Seguela, P., and Bourque, C. W. (2005). An N-terminal variant of Trpv1 channel is required for osmosensory transduction. Nat. Neurosci. 9, 93-98.

Nagata, K., Duggan, A., Kumar, G., and Garcia-Anoveros, J. (2005). Nociceptor and hair cell transducer properties of TRPA1, a channel for pain and hearing. J. Neurosci. 25, 4052-4061.

Nasuhoglu, C., Feng, S., Mao, Y., Shammat, I., Yamamato, M., Earnest, S., Lemmon, M., and Hilgemann, D. W. (2002). Modulation of cardiac PIP2 by cardioactive hormones 
and other physiologically relevant interventions. Am. J. Physiol. Cell Physiol. 283, C223-C234.

Nauli, S. M., Alenghat, F. J., Luo, Y., Williams, E., Vassilev, P., Li, X., Elia, A. E., Lu, W., Brown, E. M., Quinn, S. J., Ingber, D. E., and Zhou, J. (2003). Polycystins 1 and 2 mediate mechanosensation in the primary cilium of kidney cells. Nat. Genet. 33, 129-137.

Nauli, S. M., and Zhou, J. (2004). Polycystins and mechanosensation in renal and nodal cilia. Bioessays 26, 844-856.

Nicolson, T. (2005). Fishing for key players in mechanotransduction. Trends Neurosci. 28, 140-144.

Nilius, B. (2004). Is the volume-regulated anion channel VRAC a "water-permeable" channel? Neurochem. Res. 29, 3-8.

Nilius, B., and Droogmans, G. (2001). Ion channels and their functional role in vascular endothelium. Physiol. Rev. 81, 1415-1459.

Nilius, B., Owsianik, G., Voets, T., and Peters, J. A. (2007). Transient receptor potential channels in disease. Physiol. Rev. 87, 165-217.

Nilius, B., Prenen, J., Voets, T., Eggermont, J., and Droogmans, G. (1998). Activation of volume-regulated chloride currents by reduction of intracellular ionic strength in bovine endothelial cells. J. Physiol. (Lond.) 506, 353-361.

Nilius, B., Prenen, J., Wissenbach, U., Bodding, M., and Droogmans, G. (2001). Differential activation of the volume-sensitive cation channel TRP12 (OTRPC4) and volumeregulated anion currents in HEK-293 cells. Pflüg. Arch. Eur. J. Physiol. 443, 227-233.

Nilius, B., and Voets, T. (2005). Trp channels: A TR(I)P through a world of multifunctional cation channels. Pflüg. Arch. Eur. J. Physiol. 451, 1-10.

Numata, T., Shimizu, T., and Okada, Y. (2006). TRPM7 is a stretch- and swelling-activated cation channel involved in volume regulation in human epithelial cells. Am. J. Physiol. Cell Physiol. 292, C460-C467.

O'Neil, R. G., and Heller, S. (2005). Mechanosensitive nature of TRPV channels. Pflüg. Arch. Eur. J. Physiol. 451, 193-203.

Oancea, E., Wolfe, J. T., and Clapham, D. E. (2006). Functional TRPM7 channels accumulate at the plasma membrane in response to fluid flow. Circ. Res. 98, 245-253.

Oberwinkler, J., Lis, A., Giehl, K. M., Flockerzi, V., and Philipp, S. E. (2005). Alternative splicing switches the divalent cation selectivity of TRPM3 channels. J. Biol. Chem. 280, 22540-22548.

Palmer, C. P., Zhou, X. L., Lin, J., Loukin, S. H., Kung, C., and Saimi, Y. (2001). A TRP homolog in Saccharomyces cerevisiae forms an intracellular $\mathrm{Ca}^{2+}$ - permeable channel in the yeast vacuolar membrane. Proc. Natl. Acad. Sci. USA 98, 7801-7805.

Patel, A. J., and Honore, E. (2001). Properties and modulation of mammalian 2P domain $\mathrm{K}^{+}$ channels. Trends Neurosci. 24, 339-346.

Patel, A. J., Honore, E., Maingret, F., Lesage, F., Fink, M., Duprat, F., and Lazdunski, M. (1998). A mammalian two pore domain mechano-gated S-like $\mathrm{K}^{+}$channel. EMBOJ. 17, 4283-4290.

Pedersen, S. F., Beisner, K. H., Hougaard, C., Willumsen, B. M., Lambert, I. H., and Hoffmann, E. K. (2002). Rho family GTP binding proteins are involved in the regulatory volume decrease process in NIH3T3 mouse fibroblasts. J. Physiol. 541, 779-796.

Pedersen, S. F., Hoffmann, E. K., and Mills, J. W. (2001). The cytoskeleton and cell volume regulation. Comp. Biochem. Physiol. A Mol. Integr. Physiol. 130, 385-399.

Pedersen, S. F., Owsianik, G., and Nilius, B. (2005). TRP channels: An overview. Cell Calcium 38, 233-252.

Pedersen, S. F., Poulsen, K. A., and Lambert, I. H. (2006). Roles of phospholipase A2 isoforms in the swelling- and melittin-induced arachidonic acid release and taurine efflux in NIH3T3 fibroblasts. Am. J. Physiol. Cell Physiol. 291, C1286-C1296. 
Penna, A., Juvin, V., Chemin, J., Compan, V., Monet, M., and Rassendren, F. A. (2006). PI3-kinase promotes TRPV2 activity independently of channel translocation to the plasma membrane. Cell Calcium 39, 495-507.

Perozo, E. (2006). Gating prokaryotic mechanosensitive channels. Nat. Rev. Mol. Cell Biol. 7, 109-119.

Ramsey, I. S., Delling, M., and Clapham, D. E. (2006). An introduction to TRP channels. Annu. Rev. Physiol. 68, 619-647.

Rohacs, T. (2007). Regulation of TRP channels by PIP(2). Pflüg. Arch. 453, 753-762.

Sakmann, B., and Neher, E. (1995). "Single-Channel Recording." Plenum Press, New York.

Sotomayor, M., Corey, D. P., and Schulten, K. (2005). In search of the hair-cell gating spring elastic properties of ankyrin and cadherin repeats. Structure 13, 669-682.

Spassova, M. A., Hewavitharana, T., Xu, W., Soboloff, J., and Gill, D. L. (2006). A common mechanism underlies stretch activation and receptor activation of TRPC6 channels. Proc. Natl. Acad. Sci. USA 103, 16586-16591.

Stokes, A. J., Shimoda, L. M., Koblan-Huberson, M., Adra, C. N., and Turner, H. (2004). A TRPV2-PKA signaling module for transduction of physical stimuli in mast cells. J. Exp. Med. 200, 137-147.

Story, G. M., Peier, A. M., Reeve, A. J., Eid, S. R., Mosbacher, J., Hricik, T. R., Earley, T. J., Hergarden, A. C., Andersson, D. A., Hwang, S. W., McIntyre, P., Jegla, T., et al. (2003). ANKTM1, a TRP-like channel expressed in nociceptive neurons, is activated by cold temperatures. Cell 112, 819-829.

Strange, K., Denton, J., and Nehrke, K. (2006). Ste20-type kinases: Evolutionarily conserved regulators of ion transport and cell volume. Physiology (Bethesda) 21, 61-68.

Strotmann, R., Harteneck, C., Nunnenmacher, K., Schultz, G., and Plant, T. D. (2000). OTRPC4, a nonselective cation channel that confers sensitivity to extracellular osmolarity. Nat. Cell Biol. 2, 695-702.

Sukharev, S. I., Martinac, B., Arshavsky, V. Y., and Kung, C. (1993). Two types of mechanosensitive channels in the Escherichia coli cell envelope: Solubilization and functional reconstitution. Biophys. J. 65, 177-183.

Tsien, R. Y. (1989). In "Fluorescence Microscopy of Living Cells in Culture" (Y. Wang and D. Taylor, eds.). Academic Press, San Diego.

Vandebrouck, C., Martin, D., Colson-Van Schoor, M., Debaix, H., and Gailly, P. (2002). Involvement of TRPC in the abnormal calcium influx observed in dystrophic (mdx) mouse skeletal muscle fibers. J. Cell Biol. 158, 1089-1096.

Van Driessche, W., De Smet, P., and Raskin, G. (1993). An automatic monitoring system for epithelial cell height. Pflüg. Arch. Eur. J. Physiol. 425, 164-171.

Voets, T., Droogmans, G., Raskin, G., Eggermont, J., and Nilius, B. (1999). Reduced intracellular ionic strength as the initial trigger for activation of endothelial volumeregulated anion channels. Proc. Natl. Acad. Sci. USA 96, 5298-5303.

Voets, T., Talavera, K., Owsianik, G., and Nilius, B. (2005). Sensing with TRP channels. Nat. Biol. Chem. 1, 85-92.

Vriens, J., Owsianik, G., Fisslthaler, B., Suzuki, M., Janssens, A., Voets, T., Morisseau, C., Hammock, B. D., Fleming, I., Busse, R., and Nilius, B. (2005). Modulation of the $\mathrm{Ca}^{2+}$ permeable cation channel TRPV4 by cytochrome P450 epoxygenases in vascular endothelium. Circ. Res. 97, 908-915.

Vriens, J., Watanabe, H., Janssens, A., Droogmans, G., Voets, T., and Nilius, B. (2004). Cell swelling, heat, and chemical agonists use distinct pathways for the activation of the cation channel TRPV4. Proc. Natl. Acad. Sci. USA 101, 396-401.

Watanabe, H., Vriens, J., Prenen, J., Droogmans, G., Voets, T., and Nilius, B. (2003). Anandamide and arachidonic acid use epoxyeicosatrienoic acids to activate TRPV4 channels. Nature 424, 434-438. 
Welsh, D., Morielli, A., Nelson, M., and Brayden, J. (2002). Transient receptor potential channels regulate myogenic tone of resistance arteries. Circ. Res. 90, 248-250.

Wu, K. L., Khan, S., Lakhe-Reddy, S., Jarad, G., Mukherjee, A., Obejero-Paz, C. A., Konieczkowski, M., Sedor, J. R., and Schelling, J. R. (2004). The NHE1 Na ${ }^{+} / \mathrm{H}^{+}$ exchanger recruits ezrin/radixin/moesin proteins to regulate Akt-dependent cell survival. J. Biol. Chem. 279, 26280-26286.

Xu, H., Zhao, H., Tian, W., Yoshida, K., Roullet, J.-B., and Cohen, D. M. (2003). Regulation of a TRP channel by tyrosine phosphorylation: Src family kinase-dependent phosphorylation of TRPV4 on Y253 mediates its response to hypotonic stress. J. Biol. Chem. 278, 11520-11527.

Yamamoto, M., Chen, M. Z., Wang, Y. J., Sun, H. Q., Wei, Y., Martinez, M., and Yin, H. L. (2006). Hypertonic stress increases phosphatidylinositol 4,5-bisphosphate levels by activating PIP5KIbeta. J. Biol. Chem. 281, 32630-32638. 
Author Query Form

Book Series: Methods in Enzymology, 428

Chapter 10

Dear Author,

During the preparation of your manuscript for typesetting some questions have arisen. These are listed below. Please check your typeset proof carefully and mark any corrections in the margin of the proof or compile them as a separate list. This form should then be returned with your marked proof/list of corrections to Elsevier Science.

\section{Disk use}

In some instances we may be unable to process the electronic file of your article and/or artwork. In that case we have, for efficiency reasons, proceeded by using the hard copy of your manuscript. If this is the case the reasons are indicated below:
$\square$ Disk damaged
$\square$ Incompatible file format
$\square$ LaTeX file for non-LaTeX journal
$\square$ Virus infected
$\square$ Discrepancies between electronic file and (peer-reviewed, therefore definitive) hard copy.

Other:

We have proceeded as follows:
$\square$ Manuscript scanned
$\square$ Manuscript keyed in
$\square$ Artwork scanned
$\square$ Files only partly used (parts processed differently:.

\section{Bibliography}

If discrepancies were noted between the literature list and the text references, the following may apply:

$\square$ The references listed below were noted in the text but appear to be missing from your literature list. Please complete the list or remove the references from the text.

$\square$ Uncited references: This section comprises references which occur in the reference list but not in the body of the text. Please position each reference in the text or, alternatively, delete it. Any reference not dealt with will be retained in this section.

\begin{tabular}{|l|l|l|}
\hline $\begin{array}{l}\text { Query } \\
\text { Refs. }\end{array}$ & Details Required & $\begin{array}{l}\text { Author's } \\
\text { response }\end{array}$ \\
\hline AU1 & OK as edited? & \\
\hline AU2 & OK as edited? & \\
\hline AU3 & OK as edited? & \\
\hline AU4 & Only one Kraft and Harteneck provided. & \\
\hline
\end{tabular}

